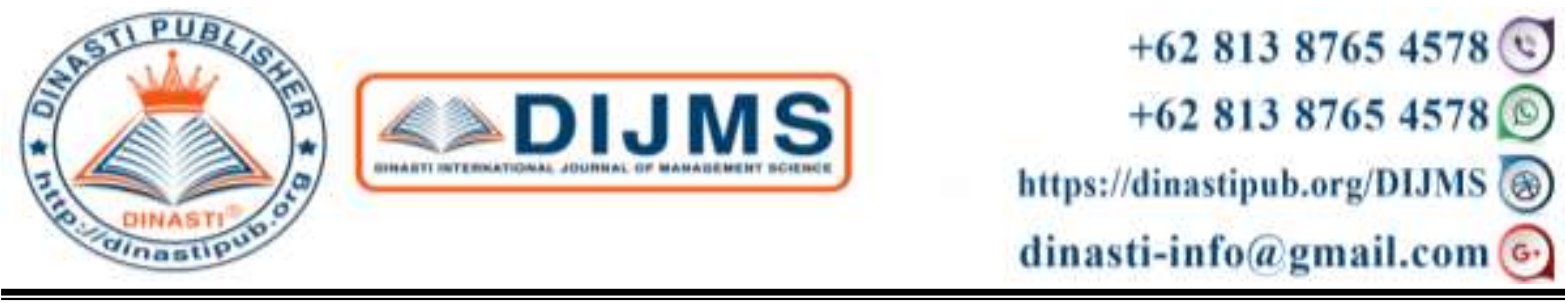

\title{
EFFECT OF WORK COMPENSATION AND MOTIVATION TOWARDS PRODUCTIVITY OF WORKERS (A SURVEY IN PT. NECIS INDAH CEMERLANG BANDUNG)
}

\author{
Deden Komar Priatna ${ }^{1}$, Devia Indriyani ${ }^{2}$, Winna Roswinna ${ }^{3}$ \\ 1) Universitas Winaya Mukti, Bandung, Indonesia \\ ${ }^{2)}$ Universitas 17 Agustus 1945, Cirebon, Indonesia \\ 3) Universitas Winaya Mukti, Bandung, Indonesia
}

\begin{tabular}{|c|c|}
\hline $\begin{array}{l}\text { ARTICLE INFORMATION } \\
\text { Received: 01 March } 2020 \\
\text { Revised: 07 March } 2020 \\
\text { Issued: } 13 \text { March } 2020 \\
\text { (filled in by Editor) } \\
\text { Corresponding author: } \\
\text { Deden Komar Priatna } \\
\text { E-mail: } \\
\text { dedenkomar@gmail.com } \\
\text { DOI:10.31933/DIJMS }\end{array}$ & $\begin{array}{l}\text { Abstract: To increase profits for companies, a highly } \\
\text { motivated workforce is needed, profit will increase if } \\
\text { supported by good work productivity of workers. The } \\
\text { achievement of these objectives depends on the policies } \\
\text { adopted by the company. But on the other hand, the work } \\
\text { productivity of workers decreases, this is due to low work } \\
\text { motivation and the relative compensation of only enough } \\
\text { for the basic needs of the lives of workers, this results in } \\
\text { targeted production not being achieved according to } \\
\text { targets set by the company, as for the goals. This study } \\
\text { aims to determine (1) compensation provided by PT. } \\
\text { Necis Indah Cemerlang Bandung, (2) motivation of } \\
\text { workers at PT. Necis Indah Cemerlang Bandung, (3) } \\
\text { work productivity at PT. Necis Indah Cemerlang } \\
\text { Bandung, and (4) the effect of compensation and } \\
\text { motivation both jointly and individually on work } \\
\text { productivity at PT. Necis Indah Cemerlang Bandung. The } \\
\text { method used is descriptive and expansive survey method } \\
\text { of the analysis unit of the workers of PT. Necis Indah } \\
\text { Cemerlang Bandung. Sampling using a random sampling } \\
\text { method and simple with a sample of (n) } 85 \text { workers. The } \\
\text { type of investigation into this study is causality, and the } \\
\text { time horizon in this study is cross-sectional and the } \\
\text { analytical method used is frequency distribution and path } \\
\text { analysis. The findings of this study are compensation and } \\
\text { motivation both jointly and individually influencing work } \\
\text { productivity workers at PT. Necis Indah Cemerlang } \\
\text { Bandung, but partially dominant motivation affects work } \\
\text { productivity rather than compensation } \\
\text { Keywords: Work Compensation, Motivation, and } \\
\text { Productivity }\end{array}$ \\
\hline
\end{tabular}




\section{INTRODUCTION}

The existence of the Indonesian economy in the global economic environment is largely determined by the level of economic efficiency. This contradicts the phenomenon of the Indonesian economic crisis which shows the weakness of the economic fundamentals and the low level of efficiency.

The significance of the role of the industrial sector in the Indonesian economy in creating national economic competitiveness is difficult to increase, except for several small and household industries, which generally still use imported raw materials. The depreciation of the rupiah against the United States dollars harms production activities, both increasing production costs and causing bankruptcy.

The phenomenon of several companies reducing the volume or stopping their business activities is very widespread, no exception with West Java. Even West Java was the most severely affected, given that both foreign and domestic investments were concentrated on this province. Nearly 60 percent of manufacturing industries are located in West Java, so the national economy is strongly influenced by the performance of industries in this area (Statistics Office of West Java Province, 2009: 235).

Obtained a picture that a company engaged in textile commodities and textile products (TPT) PT. Necis Indah Cemerlang Bandung is a company located in Bandung Regency faced with the problem of maintaining and increasing sales results. Failure to maintain and increase sales results is a very disturbing company performance. This is reasonable because sales results are an important component of company performance. If this happens, the company will experience difficulties in maintaining and developing internal resources and excellence (Day and Reibstein, 1997: 53). Companies that cannot maintain and develop internal resources and excellence are threatened with bankruptcy. According to Sucherly (2004: 2) the existence of a textile and textile product (TPT) company is very dependent on several forces that exist in the market where the TPT company operates).

Obtained a picture that a company engaged in textile commodities and textile products (TPT) PT. Necis Indah Cemerlang Bandung is a company located in Bandung Regency faced with the problem of maintaining and increasing sales results. Failure to maintain and increase sales results severely disrupts performance Considering the importance of maintaining and increasing sales results, companies engaged in textile commodities and textile products (TPT) of PT. Necis Indah Cemerlang Bandung is demanded to be able to formulate and implement appropriate strategies, both at the business unit level and the functional level. The demand to redefine and revitalize the above strategy is in line with the changing environment of the dynamic textile and textile product (TPT) industry.

In utilizing the resources available at a company, a workforce with high work productivity is needed, which is characterized by high technical skills and dedication towards achieving the company's goals. workers will have work motivation if their needs have been met because basically, the purpose of a person's work is to fulfill their needs in the hope of obtaining compensation for the form of wages/salary, and incentives. So basically people work not only to maintain their survival but also aim to achieve a better life. As said by Smith \& Wakeley (1972) in Moh. As'ad (1999: 47), that: "a person is encouraged to move because he hopes this will lead to the present situation". So work is a form of activity aimed at getting satisfaction. This does not mean that all activities are work, this depends on the motivation that underlies the activity.

As explained above, that employees work to meet needs, and the needs that exist on employees varies, such as the motivational theory of: "hierarchy of needs" from Maslow in Gibson, (2003: 340) which states that " human needs consists of five levels (hierarchy), 
namely: physiological, safety, social and esteem and self-actualization. This theory state, that a person will be motivated to meet a higher level of need if the previous or lower needs are met.

The phenomenon of labor in the textile industry and textile products (TPT) of PT. Necis Indah Cemerlang Bandung, which is a purely private company, shows that labor at the lowest level in the organizational structure, is meeting the first level of needs namely physiological needs (physical needs), such as clothing, food, shelter, and individual welfare, so they work expecting adequate compensation.

Besides compensation, to improve work productivity requires a strong work motivation from the worker, so that it can increase work satisfaction with workers, even other important factors that must be designed as best as possible to improve employee performance is compensation (Hasibuan, 2007: 166). Likewise, Ruky (2004: 69) states that two important factors that affect employee work productivity are motivation and compensation).

Workers will have work motivation if their basic needs (basic needs) have been met such as clothing, food, shelter and the welfare of individuals and their families. For employees to meet meeting physical needs requires a large enough cost, because basically, the purpose of a person's work is to meet their needs in the hope of obtaining compensation for their work. So basically people work not only to maintain their survival but also aim to achieve a better standard of living.

Thus workers will have work motivation if their life needs have been met by Maslow's level of needs because work is to meet their needs to a better standard of living.

\section{LITERATURE REVIEW Compensation}

Compensation is one of the important functions of Human Resource Management (HRM), this is by the opinion of Luthans (1992: 147), which states:

"Incentives, at the end of the motivation cycle is the incentives defined as anything that will alleviate a need and reduce a drive, thus attaining an incentive will tend to restore physiological and psychological balance and will reduce or cut off the drive. Eating food, drinking water, and obtaining friends will tend to restore the balance and reduce the corresponding drivers, food, water, and friends are the incentives in these examples"

Simamora (2002: 629) states that incentive compensation is compensation programs that link pay with productivity, to increase employee productivity to achieve a competitive advantage. So the Compensation programs pay an individual or group for exactly what it produces.

Dessler (2002: 140) argues that the use of financial compensation is financial compensation paid to workers whose production exceed predetermined standards, so it is not new, and consists of the following types of compensation: individual compensation programs, group compensation programs, plans profit sharing and gain sharing programs.

Furthermore, Siagian (2002: 268) argues that the Compensation system is to encourage higher work productivity and is classified in two main groups, namely the Compensation system at the individual level such as "Piece Work", production bonuses, commissions, "maturity" curves and Compensation for executives. Whereas the Compensation system at the group level includes, among others, production compensation, profit sharing, and cost reduction.

While Davis and Newstrom (2002: 135-134) suggest that compensation is reminiscent of the achievements of individuals, groups or organizations which includes wage deductions, commissions, bonuses, for-profits and for production. 
Whereas Robbins (2009: 246) argues that the Compensation system contains the same meaning as the variable wage, which is a part of the salary of an employee based on a measure of individual or organizational performance. The variable wage consists of wages based on deductions, bonuses, profit sharing, and profit-sharing.

From these various opinions, it can be concluded that the Compensation system is compensation given to employees based on their work performance and aims to reduce their negative actions such as corruption, undisciplined, often neglectful of duties and alleviate the necessities of life.

\section{Motivation}

Motivation or encouragement in management is only aimed at Human Resources in general and in particular subordinates. Motivation questions how to direct the power and potential for subordinates to productively succeed in achieving and realizing the goals that have been determined. Motivation questions how to encourage the enthusiasm for subordinates to work so they want to work hard and give all their abilities and skills to realize organizational goals. The organization not only expects employees who are "capable, capable and skilled", but the most important thing is that they want to work hard and are willing to achieve optimal work results. The ability, skills, and skills of employees have no meaning for the organization if they do not want to work hard by using the abilities, skills, and skills they have Hasibuan (2007: 95).

Munandar (1997: 21) argues that there are two kinds of motivational conditions. The first motivation is called an objective situation that is, goods or circumstances that are outside of a person who are usually categorized by the term incentives or incentives or goals or goals or goals to be achieved, while the second is a subjective motivational situation, which is a condition that is contained in person or often termed need or need, derive or encouragement, or motive or desire.

According to Robbins (2009: 168) in Hartono (2009: 4) Motivation is a desire to try hard to achieve organizational goals, influenced by the ability to satisfy some individual needs. Motivation, in general, is related to all efforts to achieve goals, while organizational goals can reflect a single interest related to work-related behavior.

Mangkunegara (2004: 93) cites Fillmore H. Stanford's opinion about the definition of motivation as follows: "Motivation as an energizing condition of the organism that serves to direct that organism toward the goal of a certain class". Motivation as a condition that moves people towards certain goals. Meanwhile, Hasibuan (2007: 159) defines motivation as a stimulant of desires and the driving force of one's work will”.

In a more systematic view Robbins (2009: 205), argues that the notion of motivation is as follows :

“......the willingness to exert high levels of effort to work organizational goals. Conditioned by effort ability to satisfy some individual's needs. While general motivation is concerned with an effort toward any goal, we'll barrow the focus to organizational goal to reflect on singular interest in work-related behavior".

Winardi argues that the basic components of motivation consist of needs, desires (expectations), behavior and goals (Winardi, 2002: 25). Winardi further stated that:

"There are various reasons why humans work. If we accept the view that people work for compensation, then the compensation can be broken down into two types: Extrinsic compensation for example wages/salaries, promotions, and praise ..... Intrinsic compensation, for example, a feeling of success in terms of carrying out tasks certain very interesting and challenging". 


\section{Work productivity}

Understanding productivity itself, there is various definitions as follows: Bernardin and Russell (2003: 518) states that:

"Generally, productivity refers to a ratio of output to input. Inputs may include labor hours or costs, production costs, and equipment costs. Outputs may consist of sales, earnings, market share, and defect".

The same thing also expressed by Rusli Syarif (2003: 6), namely: "Productivity is expressed by the formula: Productivity $=$ Output $/$ Input. The output size can be expressed in the form of, inter alia: (a) the number of physical units of the product/service; (b) the value of the product/service rupiah; (c) added value; (d) amount to work/work; (e) gross profit amount. Whereas the size of the input can be expressed in the form of (a) the amount of time; (b) the number of workers; (c) total to labor costs; (d) number of hours - people (man-hours); (e) number of engine hours.

According to Sulistiyani and Rosidah (2003: 199) "Productivity concerns the final problem, namely how much is the end obtained in the process of resources, in this case, involves two aspects, namely efficiency and effectiveness."

While Syarif (1996: 25) "Productivity is simply the quality produced by the amount of work done in productivity includes two basic concepts, namely the effectiveness and effectiveness.

According to Sedarmayanti (2005: 56), "Work productivity is a mental attitude (attitude of mind) that has the spirit to make improvements. That the embodiment of mental attitude is divided into two parts, namely:

1. Internal factors (self) include honesty, knowledge, discipline, responsibility, and ability.

2. External factors (situational with work) include work quality, work results, better work methods, timeliness, and better technology

\section{RESEARCH METHODS}

The study objectives of this research are descriptive and verification. The research method used is descriptive survey method and explanatory survey method.

The type of investigation into this study is causality. The unit of analysis in this study is the individual, namely the workers of PT. Necis Indah Cemerlang Bandung. The time horizon in this study is cross-sectional, that is, information from a portion of the population (sample of respondents) is collected directly from the location empirically, to find out the opinions of some populations on the object being studied.

Sources of data into this study are secondary data sources of documentation or reports available on PT. Necis Indah Cemerlang Bandung: Annual Report of Internal Control year. While the primary data in the form of compensation, work motivation, and work productivity are sourced from primary data onto questionnaires given to workers who are respondents.

The population of the study was all employees of PT. Necis Indah Cemerlang Bandung namely (N) 542 people.

The method of determining respondents used is probability sampling, which is a sampling that provides equal opportunities for each element/member of the population to be selected as a sample. To draw a sample, the authors use the formula proposed by Slovin (Sevilla, 2005: 161):

$$
\mathrm{n}=\frac{\mathrm{N}}{1+\mathrm{Ne}^{2}}
$$


Note:

$$
\begin{aligned}
& \mathrm{n}=\text { sample } \\
& \mathrm{N}=\text { Population } \\
& \mathrm{e}=\text { Critical Value }(10 \%)
\end{aligned}
$$

With a population of 542 people. and the formula used as above, the number of samples can be calculated as follows:

$$
\begin{gathered}
\mathbf{n}=\frac{\mathrm{N}}{1+\mathrm{Ne}^{2}} \\
\mathbf{n}=\frac{542}{1+542(10 \%)^{2}} \\
\mathbf{n}=\frac{542}{1+542(\mathrm{O}, \mathrm{O} 1)} \\
\mathbf{n}=\frac{542}{1+5,42}=\frac{542}{6,42}=84.4 \text { or } 85 \text { people }
\end{gathered}
$$

So that the number of samples (n) in this study were 85 people.

\section{Design of Analysis and Test Hypotheses}

Based on the method used in data collection, the variables that have an ordinal measure are then transformed into intervals using the Method of Successive Intervals. Before distributing the instruments, testing the validity and reliability is done first. The instrument validity testing was carried out using the Correlation Product Moment formula (Sugiyono, 2006: 182).

$$
r_{Y X}=\frac{n \sum_{h=1}^{n} X Y-\sum_{h=1}^{n} X \sum_{h=1}^{n} Y}{\sqrt{\left\{n \sum_{h=1}^{n} X^{2}-\left(\sum_{h=1}^{n} X\right)^{2}\right\}\left\{n \sum_{h=1}^{n} Y^{2}-\left(\sum_{h=1}^{n} Y^{2}\right)^{2}\right\}}}
$$

The analysis used consists of two types, namely: (1) descriptive analysis, especially for qualitative variables and (2) quantitative analysis, in the form of testing hypotheses using statistical tests. Quantitative analysis is emphasized to reveal the behavior of research variables, while descriptive/qualitative analysis is used to explore the behavior of causative factors. The analytical method used is a cross-sectional analysis.

Path analysis techniques require data requirements that have a measurement level of at least intervals. Because it is through methods of successive intervals.

Determine the scale value of each $\mathrm{Z}$ value using the formula:

(Density at the lower limit)-(Density at upper limit)

$$
\text { Scale Value }=\frac{(\text { Area below upper limit })-(\text { Area below lower limit })}{\text { (A) }}
$$

The hypothesis proposed is as follows: Compensation and motivation affect productivity. If the research hypothesis is stated in the statistical hypothesis is:

Hypothesis formulation

Reject Ho if $F_{\text {count }} \geq F_{\text {table }(0,05)(n-k-1)}$

Accept Ho if $\mathrm{F}_{\text {count }}<\mathrm{F}_{\text {table }(0,05)(\mathrm{n}-\mathrm{k}-1)}$

The test statistic used is: 


$$
F=\frac{(n-k-1) \sum_{i=1}^{k} p_{Y X} r_{Y X_{i}}}{k\left(1-\sum_{i=1}^{k} p_{Y X} r_{Y X}\right)}
$$

In this case, rIXy is the correlation between variables $\mathrm{X}$ and $\mathrm{Y}$ using the following formula (Rasyid, 1994: 121):

$$
r_{Y X}=\frac{n \sum_{h=1}^{n} X Y-\sum_{h=1}^{n} X \sum_{h=1}^{n} Y}{\sqrt{\left\{n \sum_{h=1}^{n} X^{2}-\left(\sum_{h=1}^{n} X\right)^{2}\right\}\left\{n \sum_{h=1}^{n} Y^{2}-\left(\sum_{h=1}^{n} Y^{2}\right)^{2}\right\}}}
$$

Test criteria, decline $\mathrm{H}_{0}$ if $\mathrm{F}>\mathrm{F}_{\alpha ;(\mathrm{k}, \mathrm{n}-\mathrm{k}-1)}$ with $\mathrm{F}_{\alpha ;(\mathrm{k}, \mathrm{n}-\mathrm{k}-1)}$ obtained from the distribution table $\mathrm{F}$ with $\alpha=5 \%$, free degrees, $\mathrm{db}_{1}=\mathrm{k}$, and $\mathrm{db}_{2}=\mathrm{n}-\mathrm{k}-1$.

If the general hypothesis (Simultaneous) in research is significant, then further testing can be done for subhipothesis (partial), which consists of:

- Compensation affects the productivity of workers at PT. Necis Indah Cemerlang Bandung.

- Motivation affects the productivity of workers at PT. Necis Indah Cemerlang Bandung.

The partial analysis of Path Analysis is as follows:

1. Calculate the multiple correlation coefficient $\mathrm{Rx} 1 \mathrm{x} 2 \mathrm{y}$ using the formula

$$
R_{x 1 \times 2 y}=\sqrt{\frac{R_{y x 1}^{2}+R_{y x 2}^{2}-2 R_{y x 1} R_{y x 2} R_{x 1 \times 2}}{1-R_{x 1 \times 2}^{2}}}
$$

2. Determine the coefficient of causality $\mathrm{r}_{\mathrm{x} 1 \mathrm{x} 2}, \mathrm{P}_{\mathrm{yx} 1}, \mathrm{P}_{\mathrm{y}}$

3. Calculating environmental influences (other) $P \varepsilon_{Y}=\sqrt{1-R_{x 1 \times 2 y}}$

4. The decision of acceptance or rejection Ho

a. Formulation of partial operational hypotheses $\left(P_{Y \mathrm{X}_{1}}\right)$

Ho: $P_{Y X_{1}}=0$, There is no effect of compensation on productivity

Hi: $P_{Y X_{1}} \neq 0$, There is an effect of compensation on productivity

b. Formulation of partial operational hypotheses $\left(P_{Y X_{2}}\right)$

Ho: $P_{Y \mathrm{X} 2}=0$, There is no motivational effect on productivity

Hi: $P_{Y X_{2}} \neq 0$, There is a motivational effect on productivity

c. Simultaneous formulation of operational hypotheses

Ho: $P_{Y \mathrm{X} 1}=P_{Y \mathrm{X} 2}=0$ There is no effect of compensation and motivation on productivity

Hi: $P_{Y \mathrm{X} 1}=P_{Y \mathrm{X} 2} \neq 0$ There is an effect of compensation and motivation on productivity

d. Decision Criteria

Decline Ho if $t_{\text {count }} \geq t_{\text {tabel }}(0,05)(n-k-1)$

Accept Ho if $\mathrm{t}_{\text {count }}<\mathrm{t}_{\text {tabel }}(0,05)(\mathrm{n}-\mathrm{k}-1)$ 


$$
\text { where } t=\frac{P_{Y \mathrm{X}_{\mathrm{i}}}}{\sqrt{\frac{\left(1-\mathrm{R}_{Y\left(\mathrm{X}_{1} \mathrm{X}_{2}\right) \cdot C_{i i}}^{(n-\mathrm{k}-1)}\right.}{(n-1)}}}
$$

Decline $\mathrm{H}_{0}$, if $\mathrm{t}_{0 \mathrm{i}} \geq \mathrm{t}_{(\alpha ; \mathrm{n}-\mathrm{k}-1)}$

\section{FINDINGS AND DISCUSSION}

Correlation between variables using Path Analysis

Tabel 2

Matriks Korelasi Antar Variable

Correlations

\begin{tabular}{|ll|r|r|}
\hline & & Compensation & \multicolumn{1}{c|}{ Motivation } \\
\hline Compensation & Pearson Correlation & 1 & $.627^{\star \star}$ \\
& Sig. (2-tailed) &. & .000 \\
& $\mathrm{~N}$ & 85 & 85 \\
\hline \multirow{2}{*}{ Motivation } & Pearson Correlation & $.627^{\star \star}$ & 1 \\
& Sig. (2-tailed) & .000 &. \\
& $\mathrm{~N}$ & 85 & 85 \\
\hline
\end{tabular}

**. Correlation is significant at the 0.01 level (2-tailed).

Source: output results SPSS

Based on the table above is a correlation matrix between variables showing the magnitude of the relationship between fellow variables both dependent and independent. The proportions of the path diagram are two independent variables $\left(X_{1}\right.$ and $\left.X_{2}\right)$ that have a relationship between variables, and each independent variable (X), as well as the correlational relationship of the outside variables $\left(\mathrm{X}_{1}\right.$ and $\left.\mathrm{X}_{2}\right)$ residual to the dependent variable $(\mathrm{Y})$. The steps to calculate the path analysis are as follows:

$P_{Y x i}=\sum_{j=1}^{k} C R_{i j} r_{Y x_{j}} \quad I=1,2$

And overall influence $\mathrm{X}_{1}$ to $\mathrm{X}_{2}$

$$
\begin{aligned}
R_{Y X_{1} X_{2} \ldots X_{7}}^{2} & =\sum_{i=1}^{k} p_{Y X_{i}} r_{Y X_{i}} \\
& =0.641
\end{aligned}
$$

While the path coefficients of other variables outside the variables $X_{1}$ to $X_{2}$ are determined through :

$$
\begin{aligned}
\mathrm{p}_{Y 1 \varepsilon 1} & =\longdiv { 1 - R _ { Y X 1 X 2 } } \\
& =0.599
\end{aligned}
$$


This means that the influence of the variables $\mathrm{X}_{1}$ and $\mathrm{X}_{2}$ together on the $\mathrm{Y}$ variable is 0.641 or $64.1 \%$ the variables $\mathrm{X}_{1}$ and $\mathrm{X}_{2}$ together affect $\mathrm{Y}$, and the rest 0.359 or $35.9 \%$ is influenced by other variables not included in the study.

Based on the theoretical framework that there is a positive influence over compensation and motivation on work productivity, the next hypothesis will be tested for the following form:

1) Simultaneous Hypothesis Testing

To find out whether the independent variables, namely compensation $\left(\mathrm{X}_{1}\right)$ and motivation $\left(\mathrm{X}_{2}\right)$ simultaneously affect the work productivity of workers (Y) of PT. Necis Indah Cemerlang Bandung, where the hypothesis statistics can be stated in the following form:

Ho: $\mathrm{Pyx} 1=\mathrm{Pyx} 2=0$

Compensation $\left(\mathrm{X}_{1}\right)$ and motivation $\left(\mathrm{X}_{2}\right)$ simultaneously no significant effect on work productivity $(\mathrm{Y})$.

$\mathrm{H} 1$ : There is at least one Pyxi $\neq 0$

Compensation $\left(\mathrm{X}_{1}\right)$ and motivation $\left(\mathrm{X}_{2}\right)$ simultaneously have a significant effect on work productivity $(\mathrm{Y})$.

$\mathrm{H} 1$ : There is at least one Pyxi $\neq 0$

The hypothesis testing is carried out through the F test statistic, provided Ho is accepted $F_{\text {count }}<F_{\text {tablw }}$ and decline Ho if $F_{\text {count }}>F_{\text {tablel. }}$. From the calculations using SPSS software the following results were obtained:

Table 3

Simultaneous Testing

\begin{tabular}{|c|c|c|c|}
\hline Alternative Hypothesis & $\mathrm{F}_{\text {count }}$ & $\mathrm{F}_{\text {table }}(5 \%)$ & Conclusion \\
\hline $\begin{array}{l}\left(\mathrm{X}_{1}, \mathrm{X}_{2}\right) \text { simultaneously } \\
\text { affect } \mathrm{Y}\end{array}$ & 73.129 & 3.23 & Significant \\
\hline
\end{tabular}

Source: calculation results through SPSS

Based on the results of these calculations, it turns out $F_{\text {count }}$ of 73,129 is greater than $t_{\text {table }} 3.23$ (Fo > F $:(k, n-k-1)(73.129>3.23)$, so the hypothesis is accepted or H0 is rejected. Means testing for individuals with hypotheses can continue to be :

2) Individual Hypothesis Testing

Individual testing is carried out when testing simultaneously rejects the null hypothesis means that there is at least one path coefficient that is not equal to zero. This test is used to determine or test the effect of each independent variable whether individually significant or not. Because the overall test produces a significant test, the next analysis is carried out with individual testing (partial testing).

$\mathrm{H}_{\mathrm{o}}=\mathrm{Pyxi}=0$

$\mathrm{H}_{1}=\mathrm{Pyxi} \neq 0$

Test statistics for each hypothesis

$$
t_{0 i}=\frac{p_{\mathrm{XXi}}}{\sqrt{\frac{\left(1-R_{\mathrm{Y}}{ }^{2} x_{1} x_{2} x_{3}\right) C r_{i i}}{n-k-1}}} \quad, i=1,2,3
$$

Decline $\mathrm{H}_{\mathrm{o}}$, if $\mathrm{t}_{\mathrm{oi}}>\mathrm{t}_{1-\alpha(\mathrm{n}-\mathrm{k}-1)}$ 
Using the distribution table $\mathrm{t}$ is obtained:

$\mathrm{t}_{0,95(85-2-1)}=\mathrm{t}_{\mathrm{table}}=1.645$

\section{Table 4}

Testing hypotheses $X_{1}$ and $X_{2}$ against $Y$

\begin{tabular}{|l|l|l|l|l|}
\hline \multicolumn{2}{|c|}{ Path coefficient } & $\mathbf{T}_{\text {count }}$ & $\mathbf{t}_{\text {table }}$ & \multicolumn{1}{c|}{ Conclusion } \\
\hline PYX $_{1}$ & 0.427 & 5.028 & 1.645 & $\begin{array}{l}\text { Ho decline } \\
\text { There is an effect of compensation } \\
\text { on work productivity }\end{array}$ \\
\hline PYX $_{2}$ & 0.460 & 5.413 & 1.645 & $\begin{array}{l}\text { Ho decline } \\
\text { There is a motivational effect on } \\
\text { work productivity }\end{array}$ \\
\hline
\end{tabular}

Source: calculation results

Based on the calculation results of the variable path coefficient $\left(\mathrm{X}_{1}\right)$ and $\left(\mathrm{X}_{2}\right)$ to $(\mathrm{Y})$, obtained using the SPSS release 23 for windows program, Thus according to the decision rule, that the prices of tcount fall in the $\mathrm{H}_{0}$ area are rejected, it means that the path coefficient is significant, so the path diagram does not change. Conceptually, it can be explained that all aspects of compensation and motivational aspects have a positive effect on work productivity.

Next will be tested the significance of the correlation coefficient between variables $\mathrm{X}_{1}$ and $\mathrm{X}_{2}$ with the following hypothesis:

With to test statistics as follows

$t=\frac{r}{\sigma_{2}}$ dan $_{2}=\frac{1}{\sqrt{n-3}}$

Decline $\mathrm{H}_{\mathrm{o}}$ If $\mathrm{t}_{\text {count }}>\mathrm{t}_{(1-\alpha / 2 ; \mathrm{n}-\mathrm{k}-1)}$

Table 5

Correlation testing between variables $X$

\begin{tabular}{|c|c|c|l|}
\hline $\begin{array}{c}\text { Correlation } \\
\text { coefficient }\end{array}$ & $\mathbf{T}_{\text {count }}$ & $\begin{array}{c}\mathbf{t}_{\text {table }} \\
\alpha=0,05\end{array}$ & \multicolumn{1}{c|}{ Conclusion } \\
\hline 0.627 & 5.677 & 1.645 & $\begin{array}{l}\text { Ho decline } \\
\text { There is a significant relationship } \\
\text { between } \mathrm{X}_{1} \text { and } \mathrm{X}_{2}\end{array}$ \\
\hline
\end{tabular}

Source: SPSS output

From the correlation test of $\mathrm{X}$ variables, it turns out tcount $>\mathrm{t}$ table, then $\mathrm{H}_{0}$ is rejected, meaning that there is a direct relationship between the compensation and motivation variables in full.: 


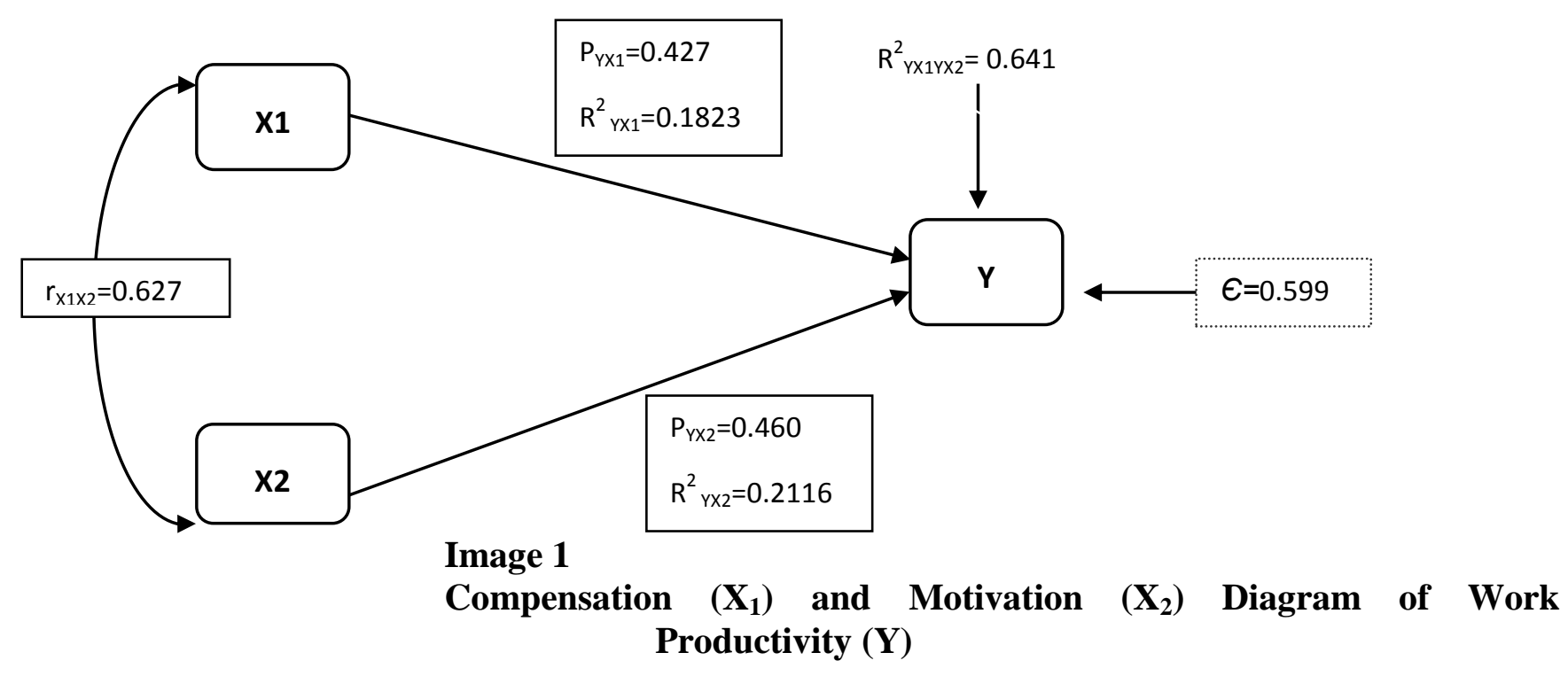

From the structural picture of the relationship between variables with the values of the structural parameters above, the effect of the cause variable to the variable, the effect of compensation and motivation on work productivity at PT. Necis Indah Cemerlang Bandung is:

Table 6

Effect of Variables X1 and X2 to Y and Effect Outside Variables X and Y

\begin{tabular}{|l|c|c|}
\hline \multicolumn{3}{|c|}{ Interpretation of Path Analysis } \\
\hline \multicolumn{1}{|c|}{ Description } & Effect & $\%$ \\
\hline Effect $\mathrm{X}_{1}, \mathrm{X}_{2}$ to $\mathrm{Y}$ & 0.641 & 64.1 \\
\hline Out of effect $\mathrm{X}_{1}, \mathrm{X}_{2, \text { and }} \mathrm{Y}$ & 0.359 & 35.9 \\
\hline Amount & & 100 \\
\hline
\end{tabular}

Source: SPSS Program of Statistics Processing Results

From the test results, it can be seen that compensation and motivation together affect the performance of $64.1 \%$, while the remaining $35.9 \%$ is influenced by other factors not examined by the author namely work climate, job satisfaction, commitment, work culture, environment work, discipline, training and leadership. However, when viewed partially, motivation is more dominant affecting work productivity than compensation. This can be understood because each indicator of compensation and motivation is used as an aspect of work productivity measurement.

Based on the above calculation results, it can be revealed that compensation for work productivity both directly and indirectly at PT. Necis Indah Cemerlang Bandung can be seen in table 7 below: 


\section{Table 7}

Direct and Indirect Effects of Compensation

Towards work productivity

\begin{tabular}{|c|l|c|c|}
\hline \multicolumn{3}{|c|}{ Interpretation of Path Analysis } \\
\hline Desc. & & Effect & \% \\
\hline $\mathbf{X}_{\mathbf{1}}$ & Direct effect on Y & 0.1823 & 18.23 \\
\hline & Indirect effect through $\mathrm{X}_{2}$ to Y & 0.1232 & 12.32 \\
\hline Amount & & 0.3055 & 30.55 \\
\hline
\end{tabular}

Source: SPSS Program of Statistics Processing Results

From the table above it can be seen that the contribution to compensation to work productivity is directly $18.23 \%$, and indirectly through the motivational variable of $12.32 \%$. While the contribution to compensation to overall work productivity reaches $30.55 \%$, this empirical evidence indicates that to increase work productivity, there needs to be an improvement and an increase in compensation factors, because compensation is closely related to an increase in work productivity. The path coefficient shows a positive and significant value, meaning that if the compensation received by workers increases, it is estimated that workforce productivity will increase as well. that compensation has an impact on employee recruitment, motivation, productivity, and turnover. Thus the compensation and work productivity of workers can not be separated from each other interrelated, because the main purpose of the compensation program is to drive towards increasing the work productivity of workers, (Siagian, 2002: 267). Likewise, the results of the above calculation, it can be revealed that the influence of motivation on work productivity both directly and indirectly can be seen in table 8 below:

Table 8

Direct and Indirect Effects of Motivation on Work Productivity

\begin{tabular}{|c|l|c|c|}
\hline \multicolumn{3}{|c|}{ Interpretation of Path Analysis } \\
\hline Desc & & Pengaruh & $\%$ \\
\hline $\mathbf{X}_{\mathbf{2}}$ & Direct influence on Y & 0.2116 & 21.16 \\
\hline & Indirect influence through $\mathrm{X}_{1}$ to Y & 0.1232 & 12.32 \\
\hline Amount & & 0.3348 & 33.48 \\
\hline
\end{tabular}

Source: SPSS Program of Statistics Processing Results

From the table above it can be seen that the contribution to motivation to work productivity is directly at $21.16 \%$, and indirectly through the compensation variable at $12.32 \%$. While the contribution to motivation to overall work productivity reaches $33.48 \%$. This means that the more precise Motivation, it will increase their work productivity, because motivation has a significant effect on work productivity, PT. Necis Indah Cemerlang Bandung, who has a positive motivation for her field of work, wants to achieve high and a conducive work environment is needed. The work environment is anything that is around workers and can influence workers in carrying out the tasks entrusted to them.

In the process of increasing the work productivity of workers, it seems clear that work motivation in the task area is very influential. Therefore the more positive the work 
motivation of workers towards their field of work, the productivity of their work will increase (Siagian, 2002: 286)

The results of this analysis are in line with the opinion of Kussriyanto (2003, 115118), several factors that can motivate employees to improve work productivity are; meet the economic needs of employees, the certainty of job security and security, the certainty of work continuity, improve the performance of leaders in general, the leadership fairness in work relationships, the appropriateness of the organization's rewards for achievement, provide opportunities for growth and progress, and provide opportunities to channel/utilizes self ability so that employees will work effectively and efficiently, in turn, it is expected to support work productivity and help smooth the wheels of activities of an organization.

\section{CONCLUSION AND SUGGESTION CONCLUSION}

1. Compensation is given to workers of PT. Necis Indah Cemerlang Bandung is currently considered quite adequate, but some things need to be considered, namely, workers who work beyond the production target is not given a decent bonus, social benefits provided by the company are less feasible, annual ban is never given even though the company has profits, workers not allowed promotion to a higher level, environmental conditions in the workplace are less conducive, supervisors (supervision) at work are less competent, leaders do not respect the work of workers

2. The motivation of PT. Necis Indah Cemerlang Bandung is quite good, in the sense that the current working conditions are sufficient to meet their basic needs, but several things need to be considered, namely the absence of certainty of continuity of work, the absence of opportunities/opportunities to develop progress, lack of being allowed to channel/utilize capabilities

3. PT. Necis Indah Cemerlang Bandung is quite good, but some things need to be considered, namely giving compensation for workers not by the level of education and knowledge of workers.

4. Compensation and motivation together affect the work productivity of workers at PT. Necis Indah Cemerlang Bandung, but partially dominant motivation affects productivity rather than compensation. Thus, the compensation given to workers is very influential on the level of job satisfaction and work motivation, as well as work results and/or productivity of workers themselves and high motivation, which will increase commitment to the organization, namely individual or group work productivity.

\section{SUGGESTION}

1. Efforts to improve compensation for the fairness and fairness of the payment system to increase to labor productivity can be done as follows, (1) given an appropriate bonus for workers who work beyond the production target, (2) gives an appropriate social benefit to help workers' health, give an annual bonus, if the company has the advantage, given the opportunity for promotion to a higher level, the environmental conditions are improved, the supervisor (Supervision) must be competent, and respect the work of workers.

2. Increase the work motivation of PT. Necis Indah Cemerlang Bandung, using the certainty of continuity of work, given the opportunity/opportunity to develop to get progress, given the opportunity to channel/utilizes the ability.

3. Work productivity of workers of PT. Necis Indah Cemerlang Bandung must be further improved, especially the provision of compensation for workers must be by the level of education and knowledge possessed by workers. 
4. The dominant motivation influences work productivity rather than compensation, therefore the management of PT. Necis Indah Cemerlang Bandung is demanded to prioritize improvements in the motivation of workers with the opportunity to develop to gain progress and the opportunity to channel abilities.

\section{REFERENCE}

Achmad S. Ruky. 2004, Performance Management System, Jakarta : PT. Gramedia Pustaka utama.

Al-Rasyid, Harun. 1998. Path Analysis as a means of statistics in causal analysis. Bandung: LP3ES Faculty of Economics, UNPAD.

A.S. Munandar, 1997, Human Resource Management, Gunung Agung, Jakarta

Bambang Kusriyanto. 1999, Increase Employee Productivity, PT. Pustaka Presindo, Jakarta.

Bambang Wahyudi, 2002. Human Resource Management, Second Matter, Publisher Sulita Bandung.

Bernardin, H. John, And Russell, Joyce E. A.2003, Human Resource Management, Ney York : Mc Graw-Hill Inc.

Davis, Keith, and John W.Newstroom, 2002, Organizational Behaviour, Human Behaviour at Work, 11th Edition, McGraw-Hill Irwin, New York.

Dessler, Garry, 2002, Human Resource Management, seventh edition, language transfer. Benyamin Molan, Jakarta, PT. Prehalindo

Flipo, Edwin B, 1992, Personal Management, $6^{\text {th }}$ edition Mc Grow Hill Book Company, Singapore

Gibson, Ivancevich, Donnely, 2003. Subtitles by Djoerban Wahid. Organization and Management, Erlangga Publisher, Fourth Edition,

Hartono, 2005, Personnel Management, Yogyakarta: BPEE

Hasibuan. S, P. 2007. Basic Management, Understanding, and Problems. Jakarta. PT. Bumi Aksara.

Henry Simamora, 2002. Human Resource Management, Third Matter, Publisher STIE YKPN - YOGYAKARTA.

Keith Davis and John W. New Strom, 2002., Alih Bahasa Oleh Agus Dharma, Pelaku Dalam Organisasi, Erlangga Publisher - Jakarta, Volume 1 and 2.

Luthan, 1992, Effective Training Design, Jakarta : Gramedia Pustaka Utama.

Mangkunegara, Anwar. 2004. Corporate Human Resource Management. Second printing, Bandung: Remaja Rosda Karya

Milkovich / Boudreau, 1997, Human Resource Management, Eighth Edition Irwin, Chicago.

Bogota. Boston. Buenos Aries. Caracas. London. Madrid. Mexico City. Sydney. Toronto.

Moh As'ad 1999 Industrial psychology, Yogyakarta Liberty

Nazir Moh, 200. Research Method, Bandung: Tarsito.

Ridwan, dan Engkos Ahmad Kuncoro, 2008. How to use and interpret Path Analysis.

Alfabeta Publisher, Bandung

Rusli Syarif, 2003. Productivity, Revised Edition, Bandung: Angkasa.

Sondang P. Siagian, 2002. Human Resource Management, Third Matter, Publisher Bumi Aksara - Jakarta.

Sedarmayanti, 2005. Human Resources and Work Productivity, Bandung: Ilham Jaya.

Stephen, P. Robbins, 2009, Human Resource Management, Eighth Edition John Wiley \&

Sons, Inc. New York Chichester Weinheim Brisbone Toronto Singapore. 
Sucherly. 2004, Competitive Advantages for Business and Non-Business Organizations,

Professor Inauguration Oration, UNPAD, Bandung.

Sugiyono. 2006. Administrative Research Methods. Bandung: Alfabeta.

Timpe, A. Dale (Ed), 1998, The Art And Science Of Business Management Productivity, New York: Kend Publishing.

Uma Sekaran, 2000. Research Methods For Business, Second Edition, Penerbit Nohnwiley \& Sons, Inc. New York Chichester Bisbone Toronto Singapore.

Vincent Gaspersz, 1998, Management Produktivitas Total, Jakarta, Gramedia Pustaka Utama Wexley dan Yukl. 1992, Motivation and Productivity, Third Edition, John Wiley \& Sons, Inc, New York. 